\title{
Dynamical Link of Peat Fires in South Sumatra and the Climate Modes in the Indo-Pacific Region
}

\author{
Raden Putra ${ }^{1}$, Edy Sutriyono ${ }^{2}$, Sabaruddin Kadir ${ }^{3}$, Iskhaq Iskandar ${ }^{*}$, and Deni Okta Lestari ${ }^{5}$ \\ ${ }^{1,5}$ Graduate School of Environmental Science, University of Sriwijaya, Indonesia \\ ${ }^{2}$ Geology Study Program, Faculty of Engineering, University of Sriwijaya, Indonesia \\ ${ }^{3}$ Faculty of Agriculture, University of Sriwijaya, Indonesia \\ ${ }^{4}$ Faculty of Mathematics and Natural Sciences, University of Sriwijaya, Indonesia
}

\author{
Keywords: \\ climate mode; \\ hotspot; \\ dry season; \\ environment.
}

Received: 2018-07-13

Accepted: 2019-04-04

Corespondent Email:

iskhaq@mipa.unsri.ac.id

\begin{abstract}
Peat fire is one of the environmental disasters occurring widespread during the dry season in South Sumatra. The region has long been recognized to have extensive peatland, hence it is considered as the vulnerable areas to fire. This study employs spatial analysis to evaluate the likely linked factors causing peat fire in the study area. Two interannual climate modes such as the El Niño - Southern Oscillation and Indian Ocean Dipole were considered to have affected the area with respect to climate anomaly at the 1995-2016 periods. This phenomenon was followed by the peat fire in many areas. There appears a close linkage between the occurrence of peat fires and climate anomaly. A number of hotspots tend to occur annually during the drought season. A significant number of hotspots took place during the 2006 pIOD and 2015 El Niño events due to a significant decrease in rainfall intensities.
\end{abstract}

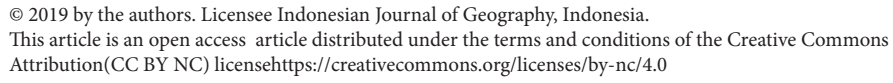

\section{Introduction}

Most of the world's peat distribution is located in the Southeast Asia (59\%), especially in Indonesia (49\%) (Dargie et al., 2017; Page et al., 2011). The peat ecosystem has a unique hydrological system, which makes it inundated along the year. The anthropogenic drainage for human needs (e.g. agriculture, plantations, etc.) has changed the hydrological system of peatlands and causes dry peatlands during the dry season. During dry conditions, peat is vulnerable to be burned because peat soils are mainly composed from organic matters (Gaveau et al., 2014; J Miettinen \& Liew, 2010; Tacconi, 2016).

Peat fire is one of the environmental disasters occurring widespread during the dry season in South Sumatra. Peat fires usually occur during the dry season from June to November (Marlier et al., 2015a; Marlier et al., 2015b) and result in a haze disaster that affects wildlife, human health, economy, and climate. Koplitz et al (2016) have mentioned that 100-300 people died in Indonesia, Malaysia, and Singapore caused by poor air quality, which is likely associated with the dispersal of haze during September-October 2015.

Several studies suggested that there are two dominant interannual climate modes in the IndoPacific region affecting the Indonesian climate, namely the El Niño - Southern Oscillation (ENSO) and Indian Ocean Dipole (IOD) (Aldrian \& Dwi Susanto, 2003; Saji \& Yamagata, 2003). Strong El Niño and positive IOD (pIOD) cause extreme deficit rainfall to occur in Indonesia, particularly in the South Sumatra region.
This study aims to evaluate a possible relationship between two climate modes in the Indo-Pacific region and peat fires during the last two decades (1995-2016). Understanding of the relationship between the climate modes in the Indo-Pacific region and peat fires is an important aspect for a better mitigation, especially in preventing the region from negative impact cause by peat fires.

\section{Methods}

South Sumatra region is located between longitudes $102^{\circ}-106^{\circ} \mathrm{E}$ and latitudes $1^{\circ}-4^{\circ} \mathrm{S}$. Based on the peatland map by Wahyunto et al (2003), South Sumatra region has 1.26 million hectares or $20 \%$ of the Indonesian peatland or $10 \%$ of the world's peatland (Wibowo \& Suyatno 1998). In the last two decades, the South Sumatra peatland has to some degree contributed to air pollution (haze), particularly when the El Niño events occurred (Huijnen et al., 2016; J Miettinen et al., 2012). Figure 1 shows the location of peatlands in the South Sumatra region, which is mostly distributed along the eastern section of the island. This study used the hotspot distribution data, relative humidity, climate anomaly index, and the monthly precipitation as shown in Table 1.

In this study, the Along Track Scanning Radiometer (ATSR) hotspot data were obtained from the ATSR Algorithm 2, in which the hotspot was identified when the terrestrial surface temperature is $>308^{\circ} \mathrm{K}$ (Arino \& Casadio, 2008). In addition, the hotspot data used 


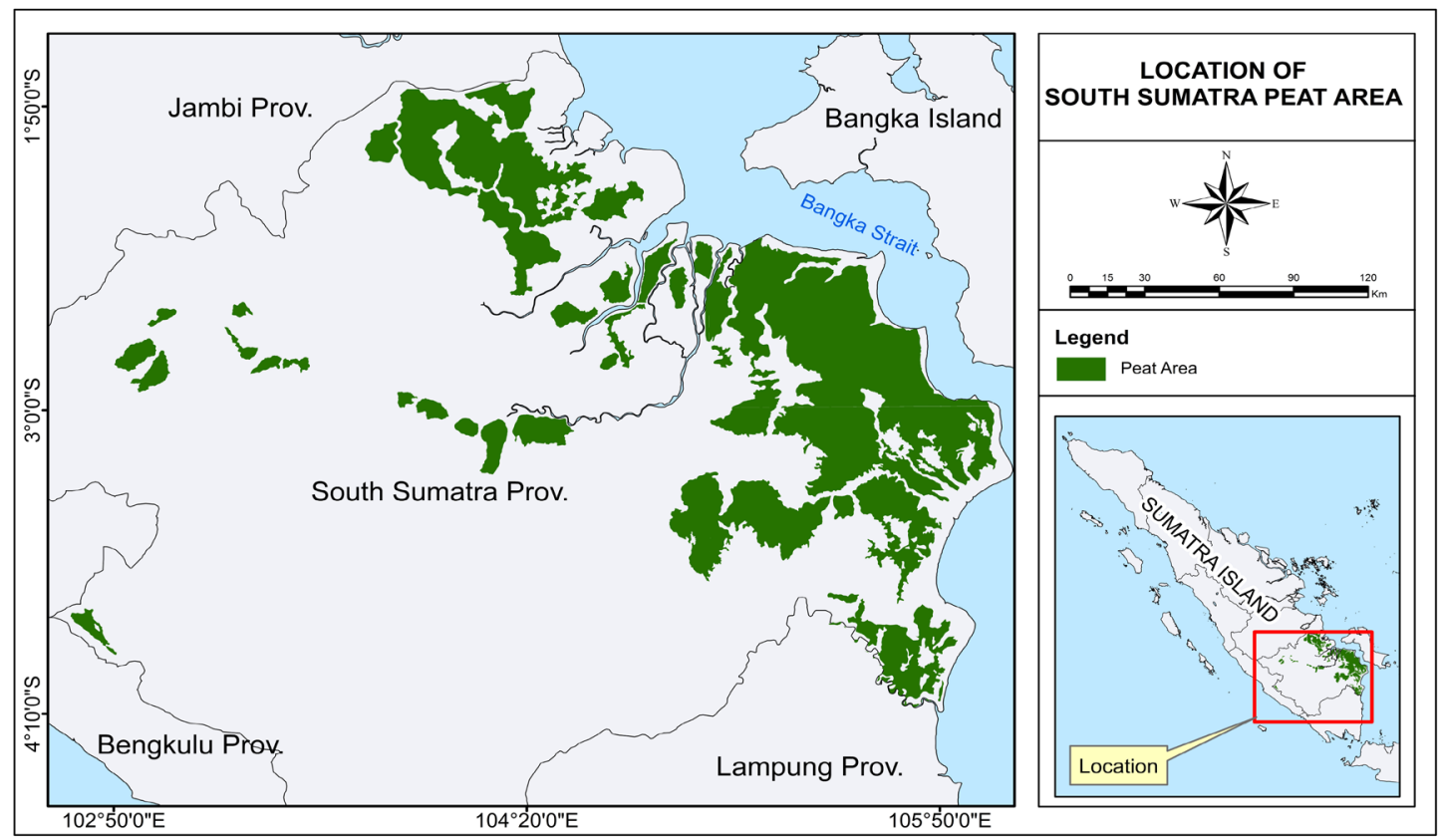

Figure 1. Location of the South Sumatra peatlands, which is indicated by green shading.

Table 1. A data set used to evaluate the distribution of peat fires in the present study area

\begin{tabular}{|c|c|c|c|}
\hline Data & Periods & Source & Resolution \\
\hline \multirow[t]{2}{*}{ Hotspot } & $1995-2002$ & $\begin{array}{l}\text { Along Track Scanning Radiometer World Fire } \\
\text { Atlas (ATSR-WFA) http://due.esrin.esa.int/ } \\
\text { page_wfa.php }\end{array}$ & $1 \mathrm{~km}$ \\
\hline & 2003-2016 & $\begin{array}{l}\text { Fire Information for Resource Management } \\
\text { System (FIRMS) https://firms.modaps.eosdis. } \\
\text { nasa.gov }\end{array}$ & $1 \mathrm{~km}$ \\
\hline Relative Humidity & $1995-2016$ & $\begin{array}{l}\text { European Centre for Medium-Rang Weather } \\
\text { Forecasts (ECMWF) https://www.ecmwf.int }\end{array}$ & $0.125^{\circ} \times 0.125^{\circ}$ \\
\hline \multirow[t]{2}{*}{ Monthly Precipitation } & 1995-1999 & $\begin{array}{l}\text { Global Precipitation Climatology Centre } \\
\text { (GPCC) http://www.esrl.noaa.gov/psd/data/ } \\
\text { gridded/data.gpcc }\end{array}$ & $0.25^{\circ} \times 0.25^{\circ}$ \\
\hline & $2000-2016$ & $\begin{array}{l}\text { Tropical Rainfall Measuring Mission (TRMM) } \\
\text { https://mirador.gsfc.nasa.gov }\end{array}$ & $0.25^{\circ} \times 0.25^{\circ}$ \\
\hline Niño3.4 index \& DMI & $1995-2016$ & $\begin{array}{l}\text { Ocean Observations Panel and Climate (OOPC) } \\
\text { https://stateoftheocean.osmc.noaa.gov }\end{array}$ & \\
\hline
\end{tabular}

represent the total hotspot during the dry season from June to November in each year for a period of 19952016. Meanwhile, the humidity, monthly precipitation, and climate anomaly index are the average values for observation from June to November each year. A spatial analysis was used to identify the dynamical relation between the hotspot distribution and the precipitation anomaly during the peak of the extreme drought.

The relative humidity data were gained from the European Centre for Medium-Rang Weather Forecasts (ECMWF) ERA-Interim for the period of January 1995 until December 2016. The data have horizontalresolution of $0.125^{\circ} \mathrm{x} 0.125^{\circ}$. The monthly precipitation data utilized the level 3 product (TPMA/3B43) of the Tropical Rainfall Measuring Mission (TRMM). This product was produced by calibrated TRMM with microwaveinfrared precipitation and merged with other satellite and rain gauges data. Two types of climate index have been used to represent climate variability in the IndoPacific region, namely the Niño3.4 index for the ENSO event and Dipole Mode Index (DMI) for the IOD event. These indices were calculated on the basis of NOAA Extended Reconstructed Sea Surface Temperature (ERST) v5.

The DMI was defined by differences of sea surface temperature (SST) anomaly between the tropical western Indian Ocean $\left(50^{\circ} \mathrm{E}-70^{\circ} \mathrm{E}, 10^{\circ} \mathrm{S}-10^{\circ} \mathrm{N}\right)$ and south-eastern tropical Indian Ocean $\left(90^{\circ} \mathrm{E}-110^{\circ} \mathrm{E}, 10\right.$ ${ }^{\circ} \mathrm{S}$ - equator). Based on the previous study, if the annual mean of DMI is either above $0,5^{\circ} \mathrm{C}$ or less than $-0,5^{\circ} \mathrm{C}$ 
is defined respectively as a positive or negative IOD event. The strong positive IOD event is characterized by the DMI above $1^{\circ} \mathrm{C}$, whereas the strong negative IOD is commonly below $-1^{\circ} \mathrm{C}$ (Saji et al., 1999; Rao et al., 2002). The Niño3.4 index is obtained by averaging the SST anomaly in the central equatorial Pacific, extending from $5^{\circ} \mathrm{N}$ to $5^{\circ} \mathrm{S}$, and $170^{\circ} \mathrm{W}$ to $120^{\circ} \mathrm{W}$ (McPhaden, 2008). If the 3-month average of Niño3.4 index is above $0,5^{\circ} \mathrm{C}$ and below $-0,5^{\circ} \mathrm{C}$ for 5 consecutive months, it is referred to as El Niño and La Niña events. Moreover, following Golden Gate Weather Service (https:// ggweather.com), the event is classified into a weak event if Niño3.4 index ranging from 0.5 to $0.9^{\circ} \mathrm{C}$, a moderate event about 1.0 to $1.4^{\circ} \mathrm{C}$, a strong event approximately 1.5 to $1.9^{\circ} \mathrm{C}$ and a very strong event $\geq 2.0^{\circ} \mathrm{C}$.

\section{Results and Discussion}

Figure 2 shows the number of hotspots recorded in the South Sumatra peatlands during the dry season from 1995 - 2016. In addition, the climate mode indices (e.g. the Niño3.4 index and DMI) and the precipitation anomaly observed over the South Sumatra region are also shown. It showed that there existed severe peat fires in 1997, 2006, 2014 and the largest event took place in 2015. The peat fires have occurred regularly since 2002 with the exception of the 2010 and 2016 La Niña events. In the last decade except in 2014, the peat fires tend to increase during the dry season in conjunction with the SST anomalies in the Indo-Pacific region, either the El Niño or IOD events.

During 1997 and 2015, the strong El Niño and pIOD events occurred, leading to a significant decrease in precipitation over the Indonesian region including the South Sumatra (Iskandar et al., 2017a). It can be noted that the El Niño and pIOD events in 1997 and 2015 were similar in intensity; however, the number of hotspots in 2015 were more extensive than those in 1997. In addition, the 2006 strong pIOD event has occurred coincident with moderate El Niño event (Iskandar, 2012). However, the number of hotspots in 2006 was higher than that observed in 1997. This feature indicates that peat fires may occur due to several factors such as climate anomaly and/or human activities known as anthropogenic forcing.

In the study area, the changes of land use appear to have triggered the appearance of peat fires. It is important to note that there existed the number of hotspots in 2014 though the Niño3.4 index and DMI showed neutral states. The inferred factors responsible for the 2014 event have been proposed by Iskandar et al (2017b), who suggested that the presence of low SST in the Indonesian seas has led to divergence, subsequently to supressed convective condition, and eventually to a significant decrease in precipitation within the region. Thus, the 2014 fire seemed unusual as it occurs due chiefly to minimum precipitation rather than an extreme climate mode in the tropical Indo-Pacific area.

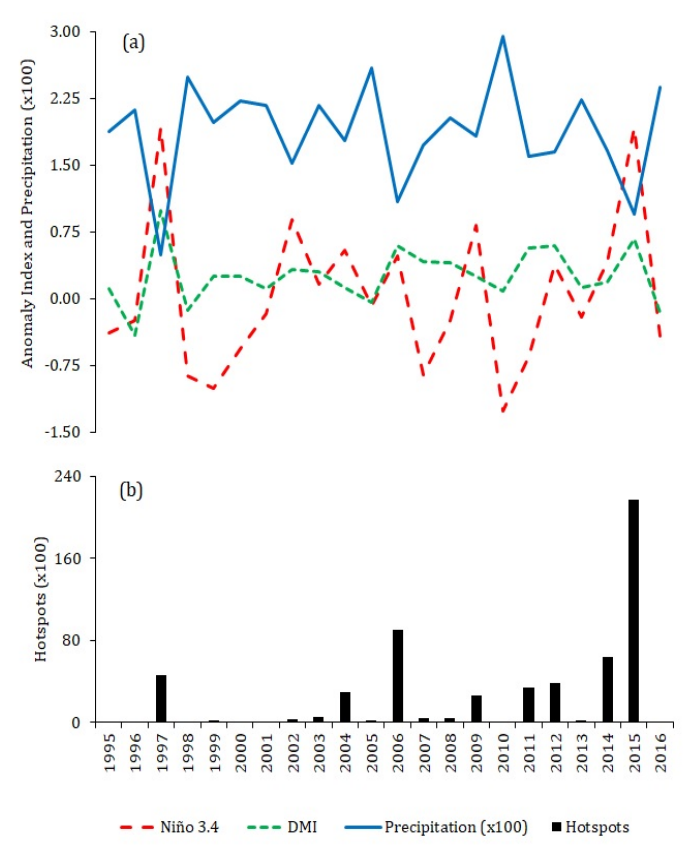

Figure 2. Diagrams showing time series of the Niño 3.4, DMI, and precipitation (a); the total hotspots (b) observed over the South Sumatra region (Note that the precipitation is divided by $100 \mathrm{~mm} /$ day for a better figure).

There were two events in 2006 and 2015 causing peat fires to occur in the region. The 2006 strong pIOD took place coincident with moderate El-Niño, whereas the 2015 strong pIOD was followed by strong El Niño. Due to these events, the western equatorial Indian ocean and eastern equatorial Pacific ocean underwent warming SST anomalies. On the other hand, the south-eastern equatorial Indian ocean and western equatorial Pacific ocean experienced cooling SST anomalies. Besides, the strong anomalous westerly winds occurred along the tropical Pacific ocean, while the strong anomalous easterly took place in the tropical Indian ocean. The cooling SST anomalies have led to strong divergence in low level winds that reduced atmospheric water evaporation. This eventually suppressed atmospheric convection allowing a decrease in precipitation in Indonesian region (Juneng \& Tangang, 2005; Lestari et al., 2018).

Figure 3 shows spatial distributions of the humidity, monthly precipitation, and hotspots during the dry season in 2006 and 2015, particularly from June to November. This feature suggests that the spatial distribution of humidity, precipitation, and hotspot were slightly distinctive in 2006 and 2015. In the 2006 pIOD event, the low humidity and negative precipitation commenced on August and reached the peak in September up to October. The event permitted the onset of hotspots in August and became more extensive from September to October 2006. This phenomenon seemed different from that in 2015. On 

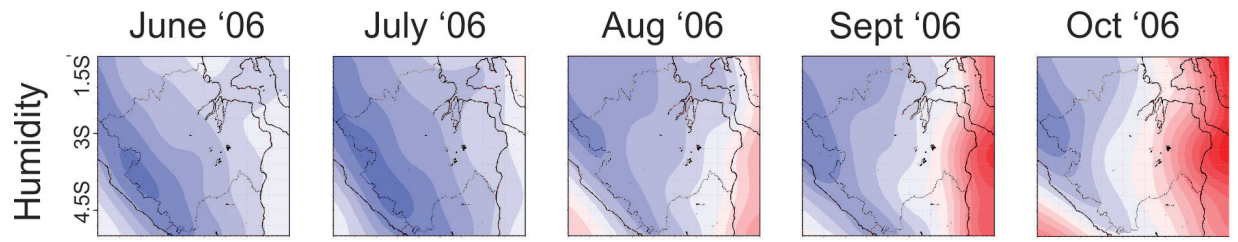

Nov '06
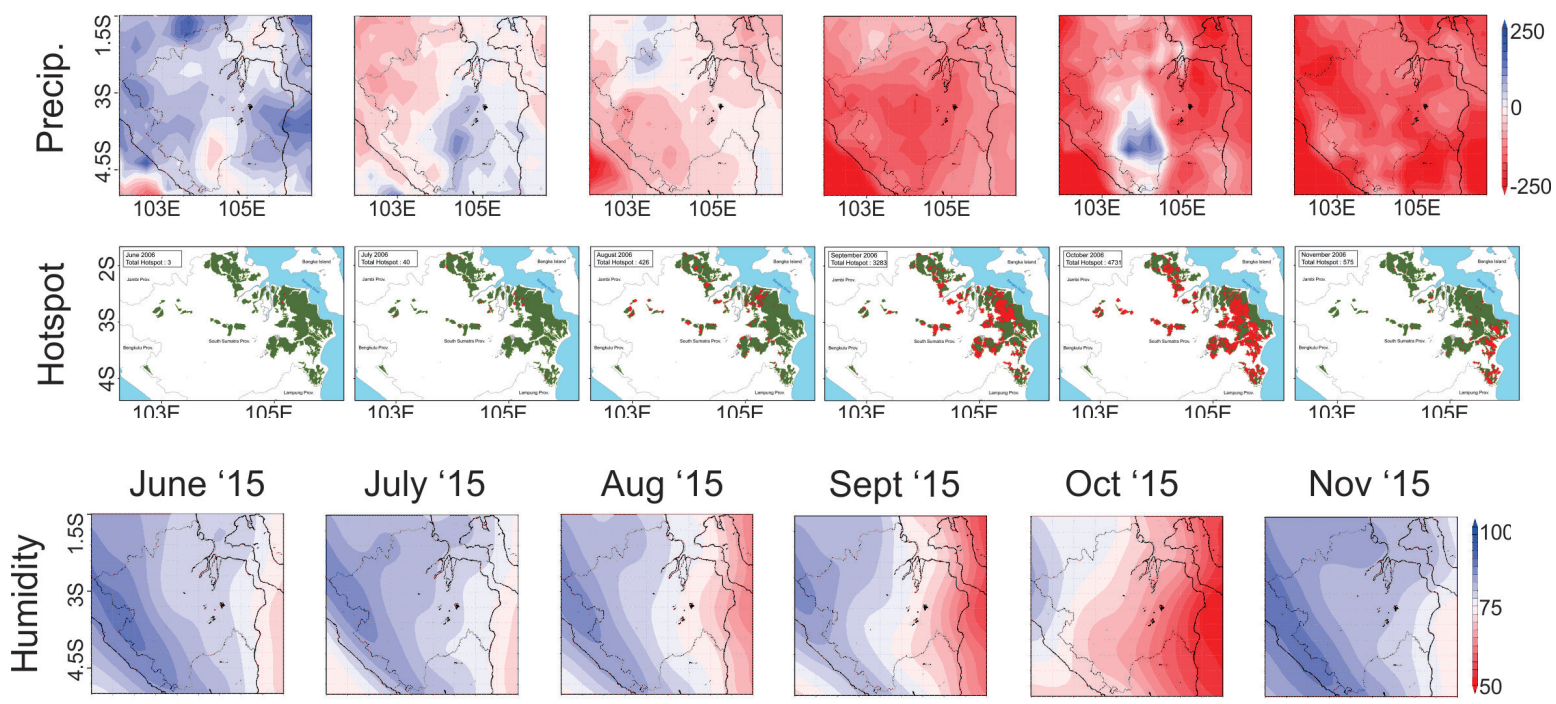

Sept '15

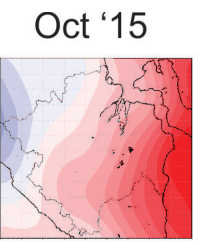

Nov'15
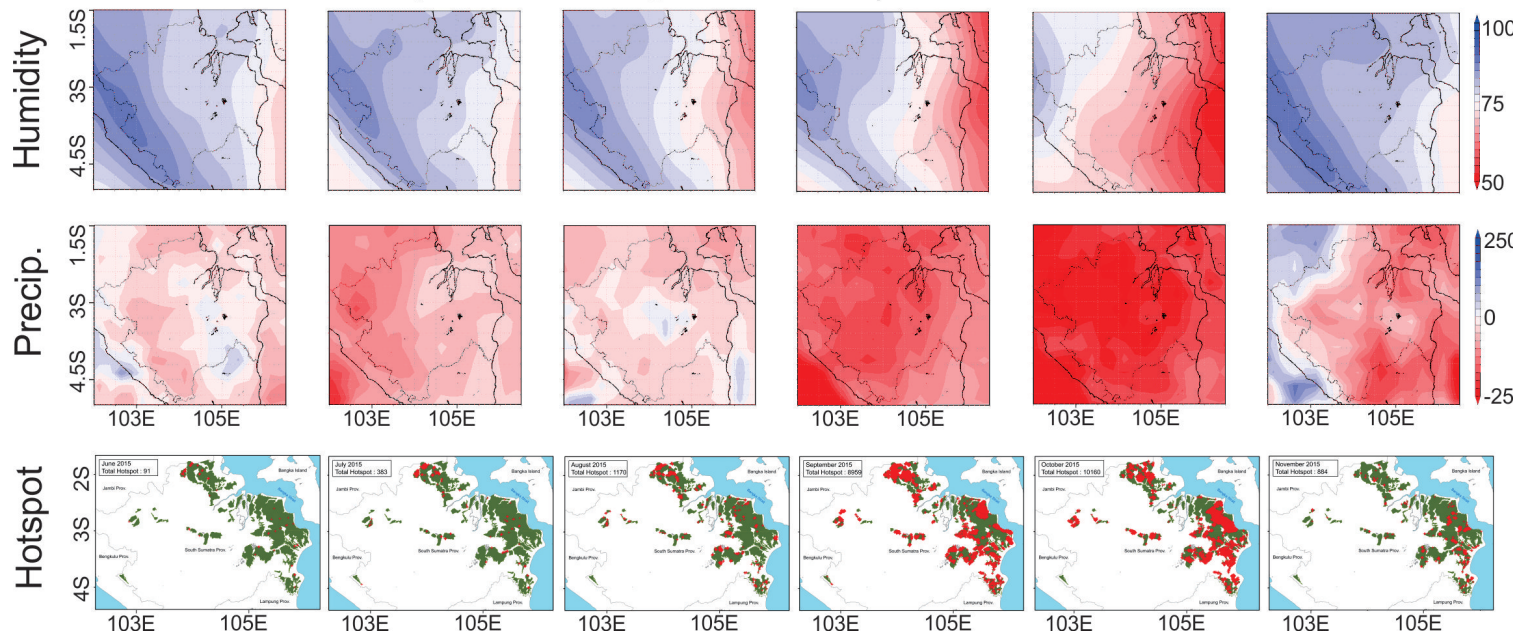

Figure 3. Spatial patterns of humidity, monthly precipitation, and hotspot distribution in the South Sumatra peatland during June - November 2006 and 2015

June 2015, the number of fires appeared as the humidity and precipitation began decreasing. In September up to October, hotspots became more extensive in the study area as the humidity and precipitation decreased more significantly.

According to Iskandar et al (2017a), a large number of hotspots existed one month prior to the peak of 2015 El Niño. It is important to note that the 2015 pIOD event ended bit earlier than the typical pIOD event. In addition, the El Niño event is usually followed by basinwide warming in the Indian ocean. This may allow the occurrence of active convections in the eastern equatorial Indian ocean which resulted in precipitation around western Indonesian region including the South Sumatera area.

\section{Conclusions}

This study reveals an apparent relationship between peat fires in the South Sumatra region and the interannual climate modes in the Indo-Pacific region. The most important factors triggering peat fires are the El Niño and pIOD events, in particular those occurring in 1997, 2006, and 2015. More importantly, the hotspots have appeared regularly since 2002, except in the 2010 and 2016 La Niña events. The present work also suggests that the lower rainfall intensity during the El Niño and/or pIOD events have significant linkages with the presence of fires in the South Sumatra region. It has been evidenced that the hotspots occurred widespread at the peak of the 2006 pIOD and $2015 \mathrm{El} \mathrm{Niño} \mathrm{in} \mathrm{conjunction} \mathrm{with} \mathrm{drought}$ season due principally to a prolong decrease in rainfall intensity.

\section{Acknowledgement}

This work is part of Doctor research funded by the Indonesian Ministry of Research, Technology and Higher Education via the PMDSU scholarship for Raden Putra and Deni Okta Lestari. 


\section{References}

Aldrian, E., \& Dwi Susanto, R. (2003). Identification of three dominant rainfall regions within Indonesia and their relationship to sea surface temperature. International Journal of Climatology, 23(12), 1435-1452. https://doi. org/10.1002/joc. 950

Arino, O., \& Casadio, S. (2008). Atsr World Fire Atlas : Can We Find a Trend In The Longest Global Fire Distribution Series? The European Space Agency World Fire Atlas project 3 . WFA Products : a Global View, 2008(1).

Dargie, G.C., Lewis, S.L., Lawson, I.T., Mitchard, E.T.A., Page, S.E., Bocko, Y.E., \& Ifo, S.A. (2017). SI: Age, extent and carbon storage of the central Congo Basin peatland complex. Nature, 61(16), 5985-5991. https://doi. org/10.1038/nature

Gaveau, D.L.A., Salim, M.A., Hergoualc'h, K., Locatelli, B., Sloan, S., Wooster, M., ... Sheil, D. (2014). Major atmospheric emissions from peat fires in Southeast Asia during non-drought years: evidence from the 2013 Sumatran fires. Scientific Reports, 4, 1-7. https://doi. org/10.1038/srep06112

Huijnen, V., Wooster, M.J., Kaiser, J.W., Gaveau, D.L.A., Flemming, J., Parrington, M., ... van Weele, M. (2016). Fire carbon emissions over maritime southeast Asia in 2015 largest since 1997. Scientific Reports, 6(February), 26886. https://doi.org/10.1038/srep26886

Iskandar, I., Utari, P. A., Lestari, D.O., Sari, Q.W., Khakim, M.Y.N., Yustian, I., \& Dahlan, Z. (2017a). Evolution of 2015 / 2016 El Niño and its impact on Indonesia. AIP Conf. Proc. 080001, 1-5. https://doi.org/10.1063/1.4987095

Iskandar, I., Mardiansyah, W., Setiabudidaya, D., Poerwono, P., Yustian, I., \& Dahlan, Z. (2017b). What did drive extreme drought event in Indonesia during boreal summer/fall 2014?. Journal of Physics: Conf. Series. 817. https://doi.org/10.1088/1742-6596/755/1/011001

Juneng, L., Tangang, F.T. (2005). Evolution of ENSO-related rainfall anomalies in Southeast Asia region and its relationship with atmosphere - Ocean variations in Indo-Pacific sector. Clim. Dyn. 25, 337-350. https://doi. org/10.1007/s00382-005-0031-6

Lestari, D.O., Sabaruddin, S., Iskandar, I., \& Sutriyono, E. (2018). Respective Influences of Indian Ocean Dipole and El Niño-Southern Oscillation on Indonesian Precipitation. J. Math. Fundam. Sci. 50, 257-272. https:// doi.org/10.5614/j.math.fund.sci.2018.50.3.3

Koplitz, S.N., Mickley, L.J., Marlier, M.E., Buonocore, J.J., Kim, P.S., Liu, T., ... Myers, S.S. (2016). Public health impacts of the severe haze in Equatorial Asia in September-October 2015: Demonstration of a new framework for informing fire management strategies to reduce downwind smoke exposure. Environmental Research Letters, 11(9). https:// doi.org/10.1088/1748-9326/11/9/094023.
McPhaden, M.J. (2008). Evolution of the 2006 - 2007 El Niño: interannual time scale dynamics. Adv. Geosci., 219-230.

Marlier, M.E., Defries, R., Pennington, D., Nelson, E., Ordway, E.M., Lewis, J., ... Mickley, L.J. (2015a). Future fire emissions associated with projected land use change in Sumatra. Global Change Biology, 21(1), 345-362. https://doi.org/10.1111/gcb.12691

Marlier, M.E., DeFries, R.S., Kim, P.S., Gaveau, D.L.A., Koplitz, S.N., Jacob, D.J., ... Myers, S.S. (2015b). Regional air quality impacts of future fire emissions in Sumatra and Kalimantan. Environmental Research Letters, 10(5), 54010. https://doi.org/10.1088/1748-9326/10/5/054010

Miettinen, J., Hooijer, A., Wang, J., Shi, C., \& Liew, S.C. (2012). Peatland degradation and conversion sequences and interrelations in Sumatra. Regional Environmental Change, 12(4), 729-737. https://doi.org/10.1007/s10113012-0290-9

Miettinen, J., \& Liew, S.C. (2010). Degradation and Development of Peatlands in Peninsular Malaysia and in the Islands of Sumatra and Borneo Since 1990, 296(February), 285-296

Page, S.E., Rieley, J.O., \& Banks, C.J. (2011). Global and regional importance of the tropical peatland carbon pool. Global Change Biology, 17(2), 798-818. https://doi. org/10.1111/j.1365-2486.2010.02279.x

Rao, S.A., Behera, S.K., \& Masumoto, Y. (2002). Interannual subsurface variability in the Tropical Indian Ocean with a special emphasis on the Indian Ocean Dipole. Deep Sea Res. II , 49, 1549-1572Saji, N. H., Goswami, B. N., Vinayachandran, P. N., \& Yamagata, T. (1999). A dipole mode in the tropical Indian Ocean. Nature, 401, 360-363

Saji, N.H., \& Yamagata, T. (2003). Possible impacts of Indian Ocean Dipole mode events on global climate. Climate Research, 25(2), 151-169. https://doi.org/10.3354/ cr025151

Saji, N.H., Goswami, B.N., Vinayachandran, P.N., \& Yamagata, T. (1999). A dipole mode in the tropical Indian Ocean. Nature, 401, 360-363.

Tacconi, L. (2016). Preventing fires and haze in Southeast Asia. Nature Climate Change, 6(7), 640-643. https://doi. org/10.1038/nclimate3008

Wahyunto, Ritung S., \& Subagjo H. (2003). Maps of area of peatland distribution and carbon content in Sumatera, 1990-2002. Wetlands International-Indonesia Programme \& Wildlife Habitat Canada (WHC), Bogor.

Wibowo P., \& Suyatno N. (1998). An overview Indonesian Wetland Sites II, Directorate General of Forest Protection and Nature Conservation and Wetlands International Indonesia Programme. 